\title{
ORIGINAL
}

\section{Glycolipid Enzyme Models. VIII. Effect of Polar Group Structures of Ethanolamine Type Phospholipids on the Enzyme Activity}

\author{
Yasukazu OHKATSU*, Tsuneo TAKEZAWA, Kazuyuki SASAKI, \\ and Takayuki ANZAI \\ Department of Applied Chemistry, Faculty of Engineering, Kogakuin Univ.
}

(1-24-2 Nishishinjuku, Shinjuku-ku, Tokyo, ₹163)

\begin{abstract}
Several ethanolamine-type phospholipids, having different head groups, were synthesized and utilized as a reaction field for hydrolyses of amino acid esters using the mixed vesicular system of a glycolipid as hydrolase model. The effect of a phospholipid on the catalytic activity was investigated. When the reaction field was in liquid-crystalline state, the glycolipid exhibited a higher hydrolytic activity in the reaction field of phospholipids having lower phase transition temperature. The field of gel state, on the other hand, gave the reverse result. These facts indicate that the hydrolytic activity of a glycolipid depends on the fluidity of the reaction field.
\end{abstract}

Key words : glycolipid, ethanolamine type phospholipid, reaction field, hydrolase model, hydrolysis

\section{Introduction}

Biomembrane is an interfacial film existing between the inside and outside of a cell, which is a fundamental unit of biobody, and contains several organelles. It participates in vital actions, such as information transfer, energy transfer, etc. Many enzymes exist in, or are bound to, the membrane, and control all kinds of reactions which are indispensable for viability. The biomembrane, which is also important from the view point that it gives a reaction field to an enzyme, can be understood by the common concept that it consists of proteins and lipids, mainly ${ }^{1}$. But the point to which we must direct our attention is the variety and complexity of the kinds and amounts of components constituting the biomembrane, depending on the organ where the membrane exists. This variety is mainly derived from the character of proteins existing in the membrane and the specified interaction among proteins and/or other cell components such as lipids. The interaction, for example, can ultimately form an organ having clear shape, such as a small intestine epithelium and a microchorion of cylinder endoplasmic reticulum, while it develops a heterogeneity on membrane. On the average, when lipids are looked at under physiological conditions, the membrane is thought to show fluidity near the liquid crystalline state $^{2)}$. This must be the best condition under which the vital activity can be maintained. That is, fluidity might be an important factor for the development of functions of biomembrane. The size and shape of alkyl groups in oily lipid substances produced in a biobody are changed, for example, to keep suitable fluidity in the cultivation of organisms, such as $E$. coli, at different temperatures. The adaptive phenomenon, thus, is observed in a molecular level ${ }^{3)}$. Viewing from these points, it will be important to clarify the interactions between a biomembrane and an enzyme. The field consisting of many kinds of lipids, which have different kinds of head groups and different chains of fatty acids, should be allowed to interact with enzymes, in diverse manners for vital actions. Unfortu-

Corresponding author : Yasukazu OHKA TSU 
nately, however, we can understand the interaction only as ordinary phenomenon concerning behavior of lipids.

We are interested in such a phenomenon. Several phospholipids, which have different hydrophilic and hydrophobic groups, were thus synthesized and used as a reaction field for hydrolyses of amino acid esters, using mixed vesicular systems of glycolipids as hydrolase model. The effect, of such a phospholipid, on the catalytic activity was investigated ${ }^{4}$. In this paper, several phospholipids, which have different phase transition temperatures, were newly synthesized and examined as reaction field. The effect, of the phase-transition temperature of reaction field, on the catalytic activity was discussed.

\section{Experimental}

\subsection{Reagents}

\section{$\dot{2 \cdot 1} \cdot 1$ Substrates}

Carbobenzoxyglycine $p$-nitrophenyl ester $\left(Z\right.$-Gly-ONp), and $p$-nitrophenylester of $\mathrm{L}^{-}$ phenylalanine ( $Z-\mathrm{L}-\mathrm{Ph} \mathrm{e}^{-\mathrm{ONp}}$ ) were used as substrates (Fig. 1). These were synthesized as described in a previous paper ${ }^{5}$.

\section{$2 \cdot 1 \cdot 2$ Catalyst}

Catalyst used in this study was a glycolipid, having the nature to self-form vesicles, which have sugar residue as a hydrophilic moiety and di- $n$-dodecyl amino residue as a hydrophobic moiety (Fig. 2 a). It was synthesized as described in a previous paper ${ }^{6}$.

$2 \cdot 1 \cdot 3$ Reaction fields

The phospholipids, as reaction fields, were synthetic phosphatidyl ethanolamine : $\mathrm{P}_{\mathrm{E}} \mathrm{E}$, monomethyl phosphatidyl ethanolamine : $\mathrm{P}_{\mathrm{E}} \mathrm{ECH}_{3}$, dimethyl phosphatidyl ethanolamine : $\mathrm{P}_{\mathrm{E}} \mathrm{E}\left(\mathrm{CH}_{3}\right)_{2}$, synthetic phosphatidyl choline : $\mathrm{P}_{\mathrm{E}} \mathrm{E}\left(\mathrm{CH}_{3}\right)_{3}$, as shown in Fig. 2. The phosphatidyl choline $\left[\mathrm{P}_{\mathrm{E}} \mathrm{E}\left(\mathrm{CH}_{3}\right)_{3}\right]$, for example, was synthesized as follows (see, Scheme 1) ; intermediates of formula $\mathrm{I}-\mathrm{V}$ being synthesized as described in a previous paper ${ }^{4}$.

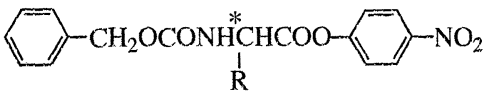

\begin{tabular}{c|c}
\hline $\mathrm{R}$ & Symbol \\
\hline $\mathrm{H}-$ & $Z$-Gly-ONp \\
\hline$-\mathrm{CH}_{2^{-}}$ & $Z_{\text {- }}-\mathrm{Phe}-\mathrm{ONp}$
\end{tabular}

Fig. 1 Structure of Substrates.

\section{Glycolipid (Enzyme model)}

a

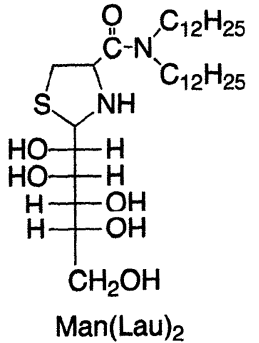

Phospholipids (Reaction field model)

b
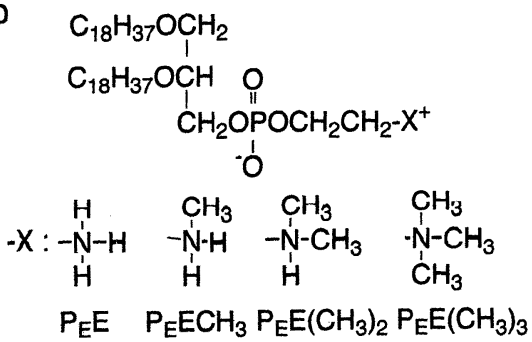

Fig. 2 A Glycolipid and Phospholipids. 


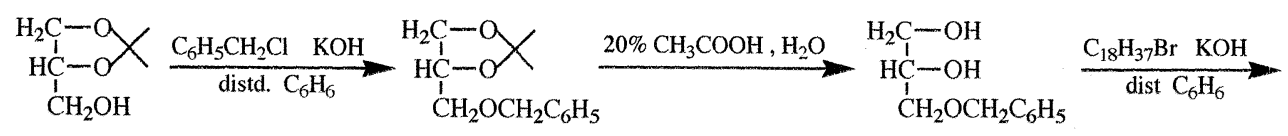

(I)

(II)
(III)

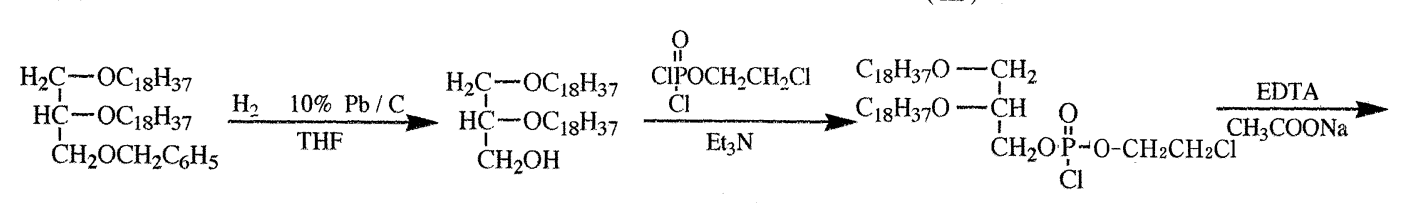

(IV) ( $\quad$ ( )

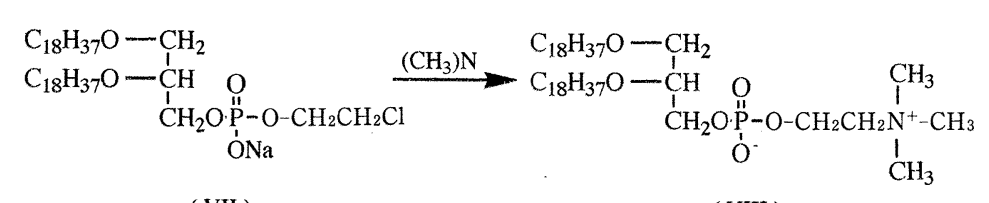

(VII)

(VIII)

Scheme 1 Synthesis of Phoshatidyl Choline $\left[\mathrm{P}_{\mathrm{E}} \mathrm{E}\left(\mathrm{CH}_{3}\right)_{3}\right]$

Synthesis of phosphatidyl choline $\left[\mathrm{P}_{\mathrm{E}} \mathrm{E}\left(\mathrm{CH}_{3}\right)_{3}\right]$

Synthesis of $\mathrm{O}$-chloroethyl dichlorophosphate

Distilled phosphorus oxychloride $(0.65 \mathrm{~mol})$ was dissolved and stirred in $25 \mathrm{~mL}$ of trichloroethylene. The distilled 2-chloroethanol (47.5 g) was added dropwise, and then the mixture was stirred at $25^{\circ} \mathrm{C}$ for $12 \mathrm{~h}$ in nitrogen atmosphere. Following the completion of the reaction, the excess phosphorus oxychloride was evaporated, at temperature below $40^{\circ} \mathrm{C}$. The vacuum distillation was carried out to produce the subject product (bp $115 \sim 119^{\circ} \mathrm{C} / 19 \mathrm{mmHg}$ ). Yield : 78.2\% (based on 2-chloroethanol).

Synthesis of 1,2-O,O-dioctadecylglycero-3-chloroethyl sodium phosphate (VII)

The $O$-chloroethyl dichlorophosphate $(9.75 \mathrm{~g})$ was dissolved in $56 \mathrm{~mL}$ of trichloroethylene, and the mixture was cooled in an ice-bath. To the mixture was added $11 \mathrm{~mL}$ of triethylamine. 1,2-O,O-Dioctadecyl glycerol ( V ) $(0.02 \mathrm{~mol})$ dissolved in trichloroethylene $(56 \mathrm{~mL})$ was then added dropwise in a water-bath, kept at room temperature, and the mixture was stirred. The completion of reaction was confirmed by TLC (chloroform : methanol=9:1).

The sediment was removed by filtration. The solvent was evaporated, and tetrahydrofran $(67 \mathrm{~mL})$ was added. The mixture was stirred, and then $67 \mathrm{~mL}$ of sodium acetate solution $(0.5 \mathrm{~mol}, \mathrm{pH} 8.5)$ and $5 \mathrm{~mL}$ of sodium ethylenediamine tetraacetate solution $(0.5 \mathrm{~mol}, \mathrm{pH}$ 10.5) was added. The completion of reaction was confirmed by consistent $\mathrm{pH}(\mathrm{pH} 7)$ of the reaction mixture.

The product was extracted with a mixture of diisopropyl ether $(60 \mathrm{~mL})$ and methanol $(20$ $\mathrm{mL}$ ). The diisopropyl ether phase was evaporated. The desired product was obtained by recrystallization from chloroform-acetone $(1: 7)$ solvent.

Yield : $69.4 \%$ [based on 1,2-O,O-dioctadecylglycero-3-chloroethyl phosphoryl chloride (VI)]. $\mathrm{mp}: 55.3^{\circ} \mathrm{C}$.

$\mathrm{IR}(\mathrm{KBr})\left(\mathrm{cm}^{-1}\right): 3450(\mathrm{C}-\mathrm{OH}), 2920,1470\left(-\mathrm{CH}_{2}{ }^{-}\right), 2850\left(-\mathrm{CH}_{3}\right), 1250(\mathrm{P}=\mathrm{O}), 1120\left(-\mathrm{CH}_{2}-\mathrm{O}^{-}\right.$ $\left.\mathrm{CH}_{2}^{-}\right), 720(\mathrm{C}-\mathrm{Cl})$.

${ }^{1} \mathrm{H}-\mathrm{NMR}\left(\mathrm{CDCl}_{3}\right.$, TMS) (ppm) : 4.2(- $\left.\mathrm{CH}_{2}-\mathrm{O}-\mathrm{P}\right), 3.6,1.3\left(-\mathrm{CH}_{2}{ }^{-}\right), 0.9\left(-\mathrm{CH}_{3}\right)$.

Elemental analysis : $\mathrm{C}_{41} \mathrm{H}_{83} \mathrm{O}_{6} \mathrm{PNCl}(761.48)$.

Calculated (\%) : $\mathrm{C}=64.7, \mathrm{H}=11.0$. 
Found (\%) : $\mathrm{C}=64.2, \mathrm{H}=11.8$.

Synthesis of 1,2-O,O-dioctadecylglycero-3-phosphatidyl choline (VII)

The literature procedure ${ }^{7)}$ was modified for preparation of this compound.

1,2-O,O-Dioctadecylglycero-3-chloroethyl sodium phosphate (VII) (3.80 g, $0.005 \mathrm{~mol})$ was dissolved in $15 \mathrm{~mL}$ of chloroform, warmed at $50^{\circ} \mathrm{C}$. 2-Propanol $(25 \mathrm{~mL})$ and acetonitrile $(25$ $\mathrm{mL}$ ) were added, and $47 \mathrm{~mL}$ of trimethylamine (30\% aqueous solution) was further added. The mixture was stirred at $50^{\circ} \mathrm{C}$. The reaction was pursued by TLC (chloroform : methanol $=3: 1$ ) and it was completed after $20 \mathrm{~h}$. The solvent was then fully evaporated.

The residue was dissolved in a mixture of water $(75 \mathrm{~mL})$, chloroform $(75 \mathrm{~mL})$, and methanol $(100 \mathrm{~mL})$. After the chloroform phase was separated, the liquid was evaporated to yield a crude product. The product was recrystallized from chloroform-acetone $(1: 7)$.

Yield : 84.7\% [based on 1,2-O,O-dioctadecylglycero-3-chloroethyl sodium phosphate (VII)]. $\mathrm{mp}: 135.5^{\circ} \mathrm{C}$.

$\mathrm{IR}(\mathrm{KBr})\left(\mathrm{cm}^{-1}\right): 3460(\mathrm{C}-\mathrm{OH}), 2940,1480,730\left(-\mathrm{CH}_{2}-\right), 2880\left(-\mathrm{CH}_{3}\right), 1390(\mathrm{~N}-\mathrm{C}), 1260(\mathrm{P}=\mathrm{O})$, $1110\left(-\mathrm{CH}_{2}-\mathrm{O}-\mathrm{CH}_{2}{ }^{-}\right), 850(-\mathrm{CHO})$.

${ }^{1} \mathrm{H}-\mathrm{NMR}\left(\mathrm{CDCl}_{3}\right.$, TMS $)(\mathrm{ppm}): 4.2\left(-\mathrm{CH}_{2}-\mathrm{O}-\mathrm{P}\right), 3.4,1.3\left(-\mathrm{CH}_{2}-\right), 0.9\left(-\mathrm{CH}_{3}\right)$.

\subsection{Differential scanning calorimetry (DSC)}

All phospholipid compounds used in this study were solid powders at room temperature. The compound $(0.3 \sim 0.4 \mathrm{mg}$ ) was weighed directly in a DSC pan. Approximately $7 \mathrm{mg}$ of water was then added, and the pan was sealed and placed along with a reference pan containing only an equivalent volume of water, in the DSC cell of a Thermal Analyst 200 from Rigakudenki Co. Ltd.. The sample was heated and cooled over a temperature range passing through the transition temperature, at least five times, and was brought to best conditions, giving reproducible results. Finally, thermal data were recorded at a heating rate of $5^{\circ} \mathrm{C}$ $/ \mathrm{min}$.

\subsection{Procedure}

A liposome solution was prepared by a thin film method. The ratio of synthetic phospholipid to glycolipid was adjusted to 0.1 , and both were added to Tris buffer ( $\mathrm{pH} 7.77$ ) and sonicated at a temperature exceeding the phase-transition temperature $\left(90^{\circ} \mathrm{C}\right)$, for $15 \mathrm{~min}$ to prepare a liposome solution, which was used as catalyst. The solution $(3 \mathrm{~mL})$ was put in a quartz cell, having a width of $1 \mathrm{~cm}$, and then an amino acid ester (1,25 $\mu \mathrm{L}$ in acetone) (Fig. 1) was added. The hydrolyses were carried out at a temperature exceeding the phase-transition temperature of phospholipids $\left(90^{\circ} \mathrm{C}\right)$, and at a temperature below it $\left(25^{\circ} \mathrm{C}\right)$. The reaction was pursued by measuring the amount of $p$-nitrophenolate ion liberated at $400 \mathrm{~nm}$ by means of a Hitachi UV-124 spectrometer.

\subsection{Kinetics}

The data obtained in this study were treated by the method described in a previous paper ${ }^{5)}$.

\section{Results and Discussion}

\subsection{Differential scanning calorimetric measurements}

Phase-transition temperatures of synthetic phospholipids were measured using a differential scanning calorimetry (DSC). The results are shown in Table 1. It is generally known that a phospholipid having a bulkier head group, such as phosphatidyl choline, has a pretransition temperature. In present experiments, a synthesized phosphatidyl choline also showed clear pretransition temperature $\left(60.0^{\circ} \mathrm{C}\right)$, and the main transition temperature was $69.3^{\circ} \mathrm{C}$. There was found to be a striking difference of the main transition temperature of synthetic phosphatidyl choline from that of phosphatidyl ethanolamine; the difference being about $20^{\circ} \mathrm{C}$. As the number of methyl groups of a head group increased, the phase-transition temperature was lowered. The main transition temperatures of di or tri-methylated phosphatidyl ethanolamines dropped dramatically, by introducing one or two methyl groups, 
Table 1 Phase Transition Temperatures of Ether Type Phospholipids.

\begin{tabular}{c|c}
\hline Phospholipids & $\begin{array}{c}\text { Phase transition } \\
\text { temperatures }\left({ }^{\circ} \mathrm{C}\right)\end{array}$ \\
\hline $\mathrm{P}_{\mathrm{E}} \mathrm{E}$ & 86.9 \\
$\mathrm{P}_{\mathrm{E}} \mathrm{ECH}$ & 82.2 \\
$\mathrm{P}_{\mathrm{E}} \mathrm{E}\left(\mathrm{CH}_{3}\right)_{2}$ & 75.0 \\
$\mathrm{P}_{\mathrm{E}} \mathrm{E}\left(\mathrm{CH}_{3}\right)_{3}$ & 69.3 \\
\hline
\end{tabular}

compared with that of monomethylated one. This result suggests that an aggregate of ethanolamine forms harder network than that of choline, probably due to hydrogen bonds ${ }^{8)}$.

\subsection{Effect of head groups on hydrolyzing activities}

Several synthetic phospholipids with different head groups, as shown in Fig. 2 (b), were utilized as a reaction field for hydrolyses of amino acid esters catalyzed by a mixed vesicular system of a glycolipid as hydrolase model. The effect of the reaction field in a gel or liquid-crystalline state on the catalytic activity was investigated. It is well known that the hydrophobic alkyl chain of a lipid is comparatively packed or fixed when the lipid membrane is in a gel state, while the membrane in a liquid crystalline state is rich in a freedom of movement (Fig. 3). From the results of DSC, all of phospholipids synthesized were found to be in liquid-crystalline state at about $90^{\circ} \mathrm{C}$ and in gel state at about $25^{\circ} \mathrm{C}$. The authors have reported, in a previous paper ${ }^{4}$, that glycolipid catalysts hydrolyze amino acid esters in the order of their respective hydrophobic natures, similarly to the discrimination activity of $\alpha$-chymotrypsin as one of hydrolases. The catalyst used in this study was the glycolipid Man(Lau $)_{2}$, having mannose and di- $n$-dodecyl amino residues, which showed the highest catalytic activity. In hydrolase model systems where phospholipids were added as reaction fields, Man $(\mathrm{Lau})_{2}$ also hydrolyzed the amino acid ester, with higher rate, having a more hydrophobic side chain. For example a phenylalanine ester is representative. Thus the effect of a phospholipid on the catalytic activity of an enzyme model is discussed in hydrolyses of the phenylalanine ester.

Figure 4 illustrates the dependence of second-order rate constants on hydrolyzing temperature using $\mathrm{Man}(\mathrm{Lau})_{2}$ in the presence of $10 \mathrm{~mol} \%$ of $\mathrm{PEE}_{\mathrm{E}}\left(\mathrm{CH}_{3}\right)_{3}$. Up to the temperature of about $60^{\circ} \mathrm{C}$, the rates of hydrolyses increase a little with the increase in reaction temperature. When the temperature increased further, the rates of hydrolyses increased dramatically. After then, namely over temperatures of about $80^{\circ} \mathrm{C}$, the reaction rate was almost constant even if the temperature was set at a higher temperature. This unique dependence of rates on reaction temperatures cannot be interpreted by the conventional relation of reaction rates with temperatures explained on the theory of activation energy. Thus the result may

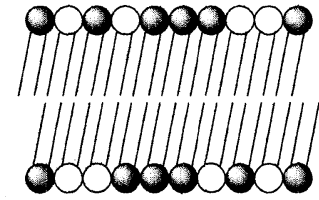

in gel state

at $25^{\circ} \mathrm{C}$

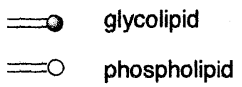

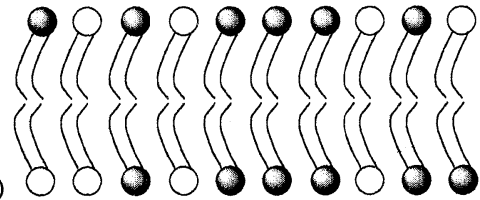

in liquid-crystalline state

at $90^{\circ} \mathrm{C}$

Fig. 3 Estimated States of Lipids Above and Below Phase Transition Temperatures. 


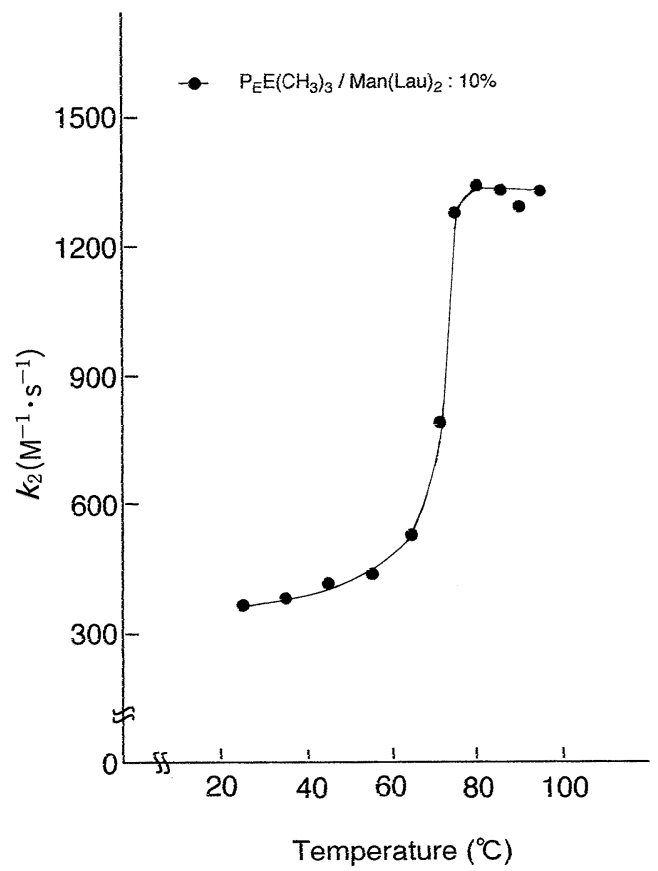

Fig. 4 Relationship between $k_{2}$ and temperature in hydrolysis of $Z-\mathrm{L}-\mathrm{Phe}-\mathrm{ONp}$ using $\operatorname{Man}(\mathrm{Lau})_{2}$ in the reaction field of phospholipid $\left[\mathrm{P}_{\mathrm{E}} \mathrm{E}\left(\mathrm{CH}_{3}\right)_{3}\right]$.

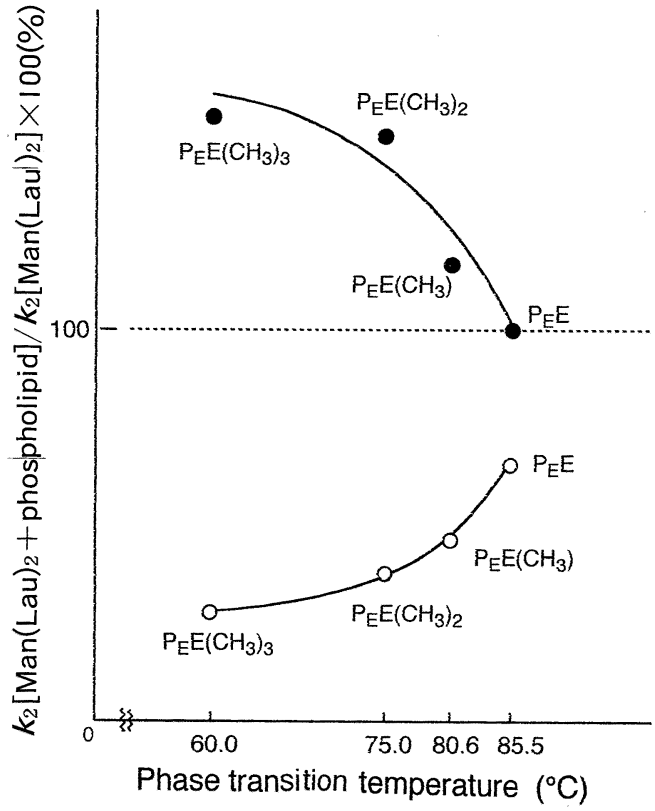

Fig. 5 Effect of Phospholipids on Activity of Man(Lau $)_{2}$ in Hydrolysis of $\left(Z^{-} \mathrm{L}^{-}\right.$ Phe-ONp).

- Liquid crystalline state $\left(90^{\circ} \mathrm{C}\right)$

$-\mathrm{O}$ - Gel state $\left(25^{\circ} \mathrm{C}\right)$

suggest different reaction modes of hydrolyses below and above $75^{\circ} \mathrm{C}$, at which the abrupt increase in the rate is observed. This temperature does not completely coincide with the phase transition temperature of $\mathrm{P}_{\mathrm{E}} \mathrm{E}\left(\mathrm{CH}_{3}\right)_{3}\left(69.3^{\circ} \mathrm{C}\right)$, but the difference of those temperatures may be ascribable to the experimental technique, because the reaction temperature on abscissa of Fig. 4 might be a little higher than a real temperature of the reaction. The reaction solution should be cooled a little during some operations that a substrate is added and mixed, and the subsequent spectroscopic measurement is carried out. The temperature where an abrupt increase in reaction rates occurs, therefore, can be assumed to correspond to the phase transition temperature of $\mathrm{P}_{\mathrm{E}} \mathrm{E}\left(\mathrm{CH}_{3}\right)_{3}$. Thus gel and liquid-crystalline states of the reaction field seem to affect reaction modes of hydrolyses.

Shown in Fig. 5, the ordinate displays the relative hydrolyzing activity of the catalyst mixed with a synthetic phospholipid, in the gel or liquid-crystalline state, and abscissa shows the phase-transition temperature of synthetic phospholipids measured by DSC. The hydrolyzing activity of the catalyst at the reaction temperature of $90^{\circ} \mathrm{C}$ was considerably higher than at $25^{\circ} \mathrm{C}$. When the reaction field was in liquid-crystalline state, a phospholipid having a lower phase transition temperature exhibited a more intensive hydrolyzing activity. The result may be explained by the following mechanism : as the number of methyl groups of a head group increases from $\mathrm{P}_{\mathrm{E}} \mathrm{E}$ to $\mathrm{P}_{\mathrm{E}} \mathrm{E}\left(\mathrm{CH}_{3}\right)_{3}$, the hydrogen bond, which is one of factors stabilizing the membrane, is weakened and, in consequence, the fluidity of a reaction field is enhanced. The field of gel state, on the other hand, gave an opposite result. The hydrolytic activity of a glycolipid catalyst decreased in terms of phospholipids added as follows : $\mathrm{P}_{\mathrm{E}} \mathrm{E}>\mathrm{P}_{\mathrm{E}} \mathrm{ECH}_{3}>\mathrm{P}_{\mathrm{E}} \mathrm{E}\left(\mathrm{CH}_{3}\right)_{2}>\mathrm{P}_{\mathrm{E}} \mathrm{E}\left(\mathrm{CH}_{3}\right)_{3}$. The result suggests that the uptake of substrate into vesicles gets worse due to the steric hindrance of a head group, as hydrogen atoms on ni- 
trogen of the head group are substituted by methyl groups, and also shows that the hydrolyzing activity of a glycolipid is affected by particular types of phospholipids (head groups).

Many enzymes, in general, would become inactive or suffer significant decreased activity, if lipids around the enzyme were in a gel state ${ }^{9}$. In this study, it was found that a glycolipid model catalyst also exhibits lower activity, when the catalyst is placed in the fields of gel state. Thus it is also certified, using model systems, that the activities of enzymes were controlled by the fluidity of reaction fields.

\subsection{Relation of fluidity of membrane with catalytic activity}

For the purpose to clarify the relation between the fluidity of membrane and the catalytic activity, the hydrolyzing activity and the substrate affinity of a glycolipid were investigated under different conditions (gel or liquid-crystalline) of reaction field. The $Z$-Gly-ONp with a hydrophilic side chain and $Z-\mathrm{L}-\mathrm{Phe}-\mathrm{ONp}$ with a hydrophobic one were selected as reaction substrates. First of all, the hydrolysis of $Z^{-} \mathrm{L}-\mathrm{Phe}-\mathrm{ONp}$ is discussed. The result is shown in Fig. 6 , in which the ordinate shows second-order rate constants $\left(k_{2}\right)$ of hydrolyses in the presence of reaction fields, and the abscissa indicates reverse values of Michealis constants $\left(K_{\mathrm{m}}\right)$; open circles show reactions in gel state, and filled circles, in liquid-crystalline state. The hydrolyzing activity of a glycolipid is found higher in the reaction field which exhibits higher substrate affinity, i.e., makes the uptake of substrate easier, regardless of the state of membranes. The slopes of straight lines are almost the same in both states.

The $Z-G l y-O N p$ as a hydrophilic substrate was, then, investigated. In this case, it was also found that $k_{2}$ is proportional to $1 / K_{\mathrm{m}}$ (Fig. 7). This fact implies that the catalytic activity is controlled by the uptake step of a substrate, depending on the kinds of phospholipids.

\subsection{Effect of conditions of membrane on substrate-distinguishing abilities}

The ratio of second-order rate constants $\left(k_{2}\right)$ for substrates, $Z^{-} \mathrm{L}^{-} \mathrm{Phe}-\mathrm{ONp}$ and $Z^{-} \mathrm{Gly}^{-}$

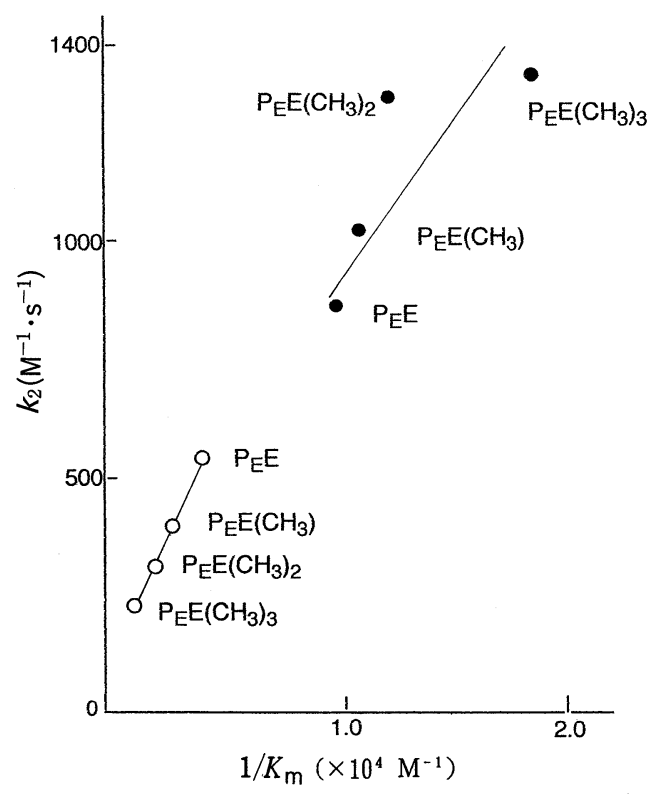

Fig. 6 Relationship between $k_{2}$ and $K_{\mathrm{m}}$ in hydrolysis of $Z-\mathrm{L}-\mathrm{Phe}-\mathrm{ONp}$ using $\operatorname{Man}(\mathrm{Lau})_{2}$.

- Liquid crystalline state $\left(90^{\circ} \mathrm{C}\right)$ - Gel state $\left(25^{\circ} \mathrm{C}\right)$

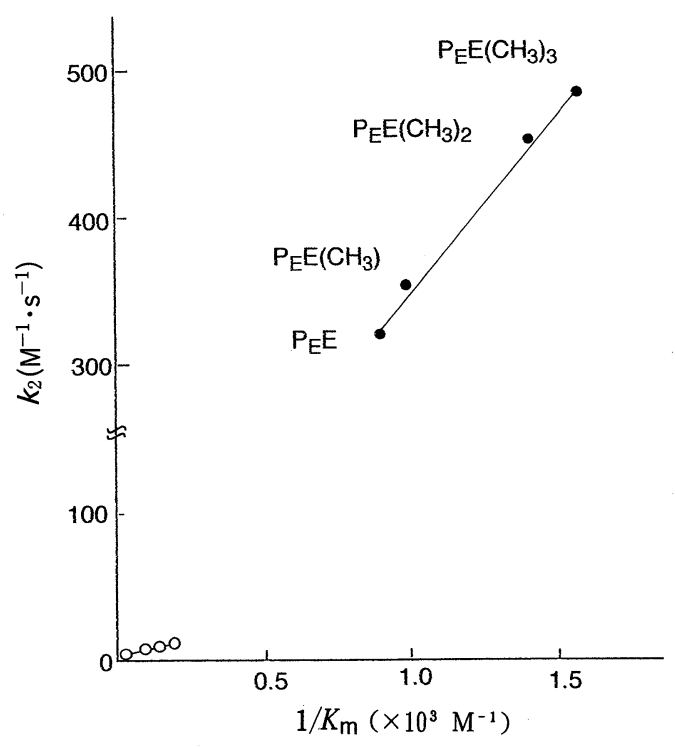

Fig. 7 Relationship between $k_{2}$ and $K_{\mathrm{m}}$ in Hydrolysis of $Z$-Gly-ONp using Man $(\mathrm{Lau})_{2}$.

Liquid crystalline state $\left(90^{\circ} \mathrm{C}\right)$ Gel state $\left(25^{\circ} \mathrm{C}\right)$ 
Table 2 Relationship between Fluidity of Reaction Field and Catalytic Activity.

\begin{tabular}{c|c|c|c|c}
\hline \multirow{2}{*}{ Phospholipid } & \multicolumn{4}{|c}{$k_{2}(Z-\mathrm{L}-\mathrm{Phe}-\mathrm{ONp}) / k_{2}(Z-\mathrm{Gly}-\mathrm{ONp})$} \\
\cline { 2 - 5 } & $\mathrm{P}_{\mathrm{E}} \mathrm{E}$ & $\mathrm{P}_{\mathrm{E}} \mathrm{ECH}_{3}$ & $\mathrm{P}_{\mathrm{E}} \mathrm{E}\left(\mathrm{CH}_{3}\right)_{2}$ & $\mathrm{P}_{\mathrm{E}} \mathrm{E}\left(\mathrm{CH}_{3}\right)_{3}$ \\
\hline Gel state & 45.7 & 40.1 & 40.1 & 41.3 \\
Liquid-crystalline state & 2.70 & 2.95 & 2.85 & 2.80 \\
\hline \multicolumn{4}{c}{ Man(Lau $)_{2}:$ Phospholipid=1:0.1 }
\end{tabular}

$\mathrm{ONp}$, was calculated in the gel or liquid-crystalline state of a reaction field (Table 2). The greater value of ratios means a higher substrate-distinguishing ability of glycolipids. It is found that values are about $40 \sim 46$ in the field of gel state and, about $2.7 \sim 3.0$ in the liquidcrystalline state, regardless of phospholipids as reaction field. The ratio in the liquid-crystalline state is considerably smaller than that in the gel state. It is well known that lipidlipid interaction in the field of liquid-crystalline state is quiet low as compared with that in gel state, i.e., that lipids in the field of liquid-crystalline state are in loose conditions, to some extent. Consequently, the substrate-distinguishing ability is presumed to be lower, because a hydrophilic substrate, which is taken in, with difficulty, in a gel state, can be taken in easily.

As a conclusion, the increase in fluidity of reaction field enhances the hydrolytic activity of glycolipid, while it lowers the substrate-distinguishing ability. The biomembrane in a biobody is thought to exist in an intermediate state, between gel and liquid-crystalline states ${ }^{10), 11)}$. This study can provide the good model to show that an enzyme activity is controlled by interactions of the enzyme with phospholipids in a biomembrane.

(Recieved : June 15, 1995 ; Accepted : Oct. 18, 1995)

\section{References}

1) J.D. Robertson, Biochemical Society Symposium 16, 3-43 (1959).

2) I.I.S. Bretscher, Biochemical Society Symposium, October, VI, (1980).

3) C.O. Rock, J.E. Cronan, Lipid Metabolism in Procaryotes. Biochemistry of Lipids and Membranes (D.E. Vance, Eds.). The Benjamin/Cummings Publishing Company, Inc., Menlo Park, California, p.73 (1985).

4) Y. Ohkatsu, T. Sueyoshi, J. Jpn. Oil Chem. Soc., 43, 1001 (1994).

5) Y. Ohkatsu, T. Sueyoshi, J. Jpn. Oil Chem. Soc., 43, 220 (1994).

6) Y. Ohkatsu, K. Hamada, M. Saitoh, J. Jpn. Oil Chem. Soc., 42, 359 (1993).

7) K. Yamauchi, M. Hihara, M. Kinoshita, Bull. Chem. Soc. Jpn., 60, 2169 (1987).

8) H. Hauser, I. Pascher, R.H. Pearson, S. Sundell, Biochim. Biophys. Acta, 650, 21-51 (1981).

9) R.B. Freedman, Membrane-bound Enzymes. Membrane Structure (J.B. Finean, R.H. Michell, Eds.), Elsevier, New York. (1981) p. 161.

10) M. Shinitzky, Membrane Fluidity and Cellular Functions. Physiology of Membrane Fluidity (M, Shinitzky, Ed.), CRC Press, Boca Raton. Vol 1, (1984) p. 1.

11) E.S. Wu, K. Jacobson, D. Papahadjopoulos, Biochemistry, 16, 3936 (1977). 


\section{日本油化学会誌本号掲載 論文要旨}

[総説] 界面活性剂の化学構造し機能の相咸に成する研究

$$
\text { 石上裕 }
$$

物質工学工業技術研究所（テ305 茨城県つくば市東1-1）

高分子界面活性剂は，高分子電解質の伸びた高分子鎖の収縮挙動によって区別される。オリゴマー型界面活性剂 (オリゴソープ)は質量作用則に従い，ミセル形成に対応して臨界ミセル濃度 $(\mathrm{cmc})$ を有していた。オリゴソープの 繰り返し単位当りの部分モル容積が，HLB值とともに実際の可溶化および乳化作用の大きさと関係づけられた。

バイオサーファクタントは，かさ高い構造にもかかわらず小さいcmcと高い表(界)面張力低下作用を示した。こ のような機能は界面での優れた分子配向性に帰せられよう。この挙動はベシクル形成および分子集合系のミセル脂質粒子-ラメラーベシクルへの変換を見出すことによって確かめられたといえよう。さらに，サーファクチンの棒 状ミセル形成は，このように高度に組織化された集合体を形成するのに有効な分子の積み重なりを可能にするため に $\beta$-シートの形成が重要であることが示唆された。バイオサーファクタントは，スピクリスポール酸におけるゲ ル形成性の乳化・分散, コリノミコール酸とラムノリピッドにおける浸透作用, サクシノイルトレハロースリピッ ドにおける多点吸着によるエマルションの安定化作用, ラムノリピッド同族体における強い界面活性などの特長を 示した。最後に, バイオミメチク・サーファクタントの調整と応用は，生体中に含まれる両親媒物質の化学構造や 生物機能を模做して, 生物科学への貢献やスペシァリティケミカルズの開発に有用であると結論された。

（連絡者：石上 裕）Vo1.45, No. 3, 229 (1996).

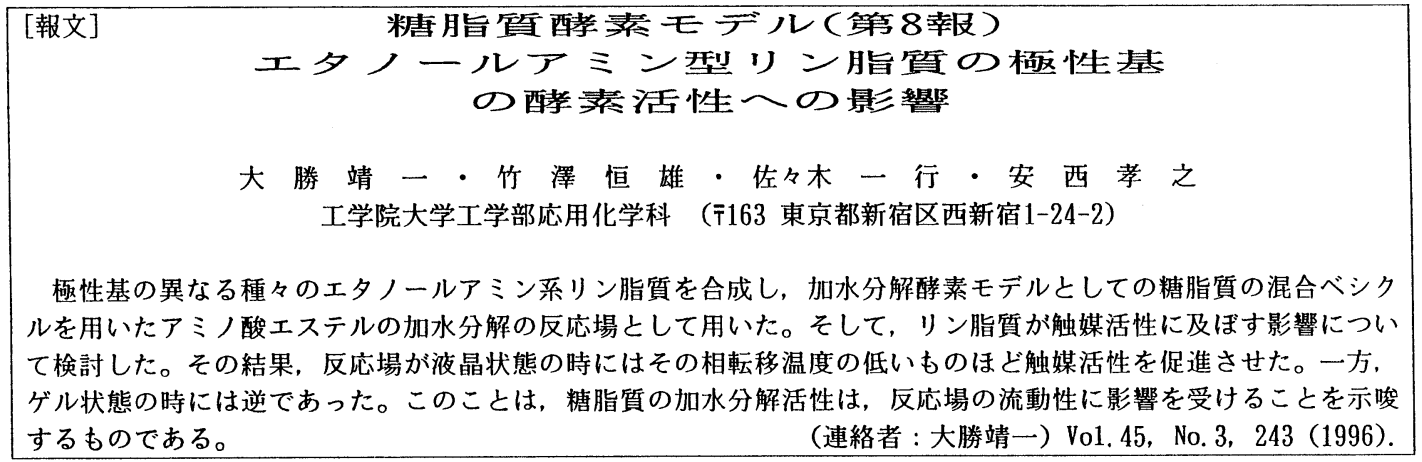

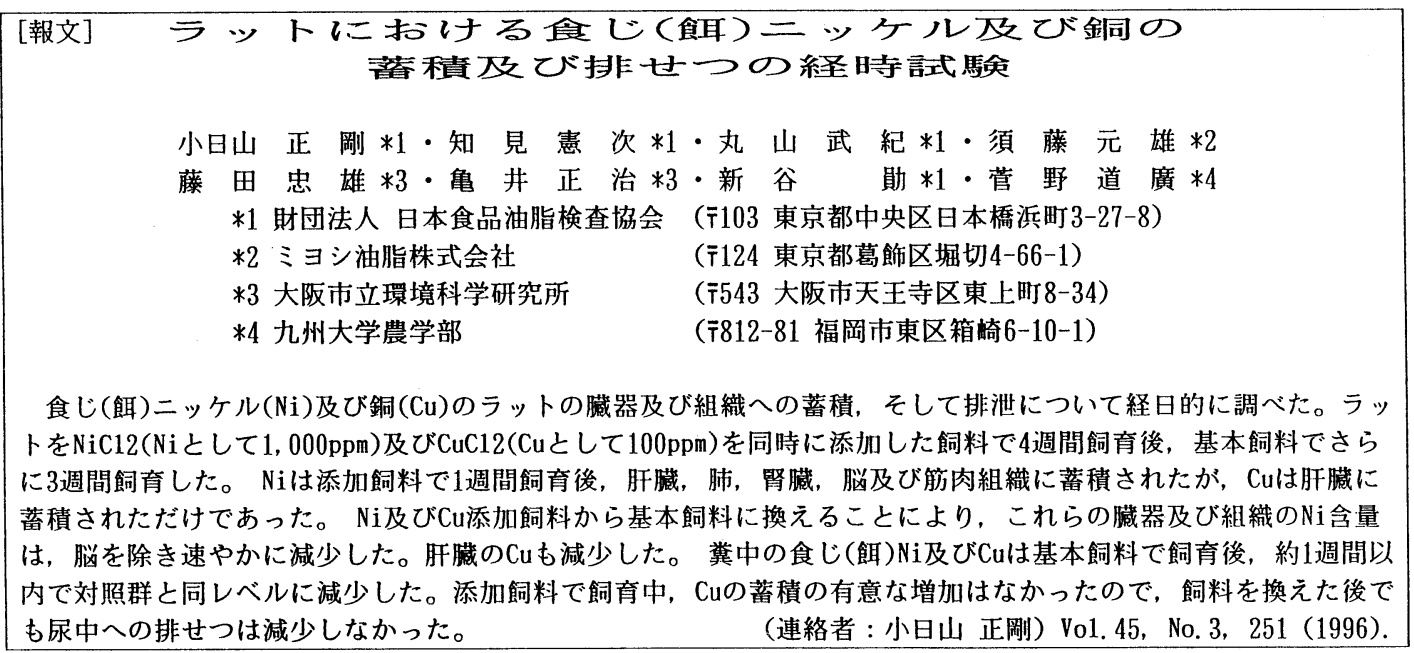

